Journal of Teacher Education for Sustainability, vol. 15, no. 2, pp. 5-24, 2013

\title{
OPPORTUNITIES AND CHALLENGES FOR INTEGRATING SUSTAINABILITY EDUCATION INTO K-12 SCHOOLS: CASE STUDY PHOENIX, AZ
}

\author{
Erin Redman \\ the National Autonomous University of Mexico, Mexico
}

\begin{abstract}
Teacher education for sustainability is a central part of integrating sustainability into classrooms and schools. However, educating for sustainability isnot limited to increased content knowledge; rather it encompasses different forms of knowledge that embrace the normative, dynamic and action-oriented nature of sustainability. Curriculum for a summer sustainability programme had previously been developed based on an interdisciplinary approach which incorporates research and practice from the fields of education pedagogy, sustainability and behaviour change. This article synthesises the insights provided by K-12 teachers who participated in this programme and another teacher who utilised the curriculum during a sustainability unit in her $8^{\text {th }}$ form science class in Phoenix, AZ. Data was collected through surveys and interviews over the course of a year. The key findings indicate that one of the major barriers to moving away from traditional, didactic approaches to education is the importance placed on standardised tests. As long as external forces and incentive structures reinforce methods of lecture and assess, teachers will struggle transitioning to more experiential, real-world methods that enhance a multiplicity of knowledge. One important suggestion made by the teachers was for increased support by universities through pre-service and in-service programmes focused on educating for sustainability.
\end{abstract}

Key words: educating for sustainability, teacher education, sustainable behaviours, education pedagogy, behaviour change, sustainability competencies

\section{Introduction}

The transition towards sustainability requires preparing educators with the knowledge and skills to implement sustainability curriculum and practices in K-12 classrooms (United Nations Educational, Scientific and Cultural Organisation, 2005). Teachers are ideally positioned to give students an active voice and promote responsible citizenry, therefore situating teacher education for sustainability as an ideal intervention point for transformative change (Makrakis \& Kostoulas-Makrakis, 2012). Unfortunately, many education programmes and teacher training programmes focus on declarative knowledge (information, scientific facts) (Cutts, Saltz, \& Elser, 2008), while neglecting the social components 
of change and action (Lukk, Veisson, \& Ots, 2008). Teachers attempting to move away from didactic, information-intensive approaches face barriers associated with the long and entrenched history of presenting knowledge as "immutable information held by experts" (DuPuis \& Ball, 2013, p. 74) as well as the top-down requirements of standards and standardised tests that reinforce lecture and assess modes of education (Lukk et al., 2008).

The research presented in this article explicitly focused on behaviour change as an intended outcome of sustainability education. Other researchers have established the need to target behaviour change as a part of sustainability initiatives, noting that the transition towards sustainability "will ultimately depend on the decisions individuals and groups make regarding their own behaviour" (Lukk et al., 2008, p. 36). Although sustainability is a relatively new field, education has long been a means for targeting behaviour change (for instance, health, drug, anti-violence programmes). In particular, environmental education programmes have attempted to foster environmentally responsible behaviours for decades (Arbuthnot, 1977; Hungerford \& Volk, 1990; Ramsey, 1993; Pooley \& O’Connor, 2000). The field of environmental education provides ample precedence for targeting behaviour change through education as well as insights into (un)successful pedagogical approaches. Although sustainability is a distinct departure from the nature-centric focus of environmental education (Pepper \& Wildy, 2008), this research draws upon the literature relating both to environmental education pedagogy and methods for promoting environmentally responsible behaviours.

This article focuses on the efforts of four K-12 teachers in Phoenix, Arizona to implement sustainability education and practices in their classrooms. During a summer sustainability education programme with primary and secondary school students held at Arizona State University in 2011, three K-12 teachers observed, participated and provided feedback to the author in developing innovative sustainability pedagogy. The summer programme was part of the teachers' master's degrees in STEM (Science, Technology, Engineering and Mathematics) education and the student participants were targeted through a mentoring programme for low-income minorities. A year-long case study was also conducted with the student participants (Redman, 2013). During the programme and the following year, interviews and surveys were conducted with the participating teachers. In addition to the three teachers that participated in the summer STEM programme, I interviewed a teacher that utilised the sustainability curriculum created for the summer programme during a two-month long sustainability unit in her $8^{\text {th }}$ form science class. While this article focuses on the qualitative data collected from a small sample of K-12 teachers, it was part of a broader effort to understand the knowledge and behaviours held by K-12 teachers regarding sustainability (Redman \& Redman, 2013).

Herein I reflect on the insights provided by the K-12 teachers concerning the opportunities and barriers to integrating sustainability into a traditional classroom setting. This article concludes with recommendations for working within the difficult, cumbersome and discipline-focused structure common in many K-12 schools, while capitalising upon existing opportunities, to advance the implementation of sustainability education. 


\section{Background}

\section{Major challenges in educating for sustainability}

Traditional approaches to education often focus on value-free, didactic, one-way methods of communication (Blumstein \& Saylan, 2007). Other scholars have noted that these mechanistic and rote education methods have exacerbated sustainability problems by promoting simplistic, isolationist thinking and by positioning the students as passive recipients of information (Orr, 2004; Williams, 2008; DuPuis \& Ball, 2013). Additionally, the long history of disciplinary and reductionist research often neglects the holistic approach advocated for by many sustainability scientists (Orr, 1991; Sipos, Battisti, \& Grimm, 2008; Nolet, 2009). The systems that train teachers (i.e., universities) as well as the structure of K-12 schools tend to reinforce positivistic, value-free views of science and didactic, expert-driven approaches to education (Owens, 2013). Clearly change within our education institutions needs to occur in order to support holistic sustainability education (Sterling, 2003).

One of the most commonly cited barriers to change within the K-12 system is the already over-crowded agenda. An education professor, Stir (2006), wrote that, "It sometimes seems that the curriculum is too crowded, the day is too busy" (p. 836). Teachers are expected to cover an ever-growing list of standards, prepare students for standardised tests and equip them with the knowledge and skills they need for their future careers. In the face of all that, educators are expected to be doing, sustainability education is often seen as an additional burden that teachers have neither the time nor resources to bear (Wheeler \& Byrne, 2003).

A number of education scholars have noted that one of the greatest pressures facing teachers is the emphasis on achieving high standardised test scores (Wheeler \& Byrne, 2003). Test scores are not only linked to funding but also often, "seal the fate and set the salaries of principals and teachers" (p. 27). This creates a barrier to implementing novel pedagogical approaches not only because teachers and students spend weeks of class time preparing for standardised tests but also because standardised tests reinforce the emphasis on technical or factual knowledge (Marzano, 1990). An education researcher Marzano (1990) wrote that "a school or district that wishes to improve student scores onstandardised achievement batteriesshould focus its curriculum on test-takingskills, content specific factualknowledge, and content specific procedural knowledge" (p. 97). While my research suggests focusing on multiple ways of knowing, with an emphasis on subjective, dynamic forms of knowledge, through experiential, real-world approaches, the pressure placed on teachers to achieve high standardised test scores reinforces didactic methods that target technical forms of knowledge.

In order for teachers to lead the way towards sustainability, they need both external and internal support. A number of sustainability education researchers have called for universities, non-governmental organisations (NGOs) and businesses to provide external support for K-12 schools (Wheeler \& Byrne, 2003). One of the ways that universities and NGOs commonly interact with K-12 teachers is through pre-service (i.e., undergraduate education programmes) and in-service training (i.e., continuing education courses). Yet, education researchers, Wheeler and Bryne (2003), lament that "in pre-service education, sustainability is totally absent as a holistic concept" and "the net result is a near-absence of sustainability education in the K-12 system” (p. 28). In addition to the 
lack of sustainability education support provided by universities and NGOs, businesses may dis-incentivise sustainability practices in schools. For instance, waste management companies often charge schools premiums for recycling bins and services. This lack of support for sustainability in pre-service and in-service training as well is in supportive business practices often leads to educators feeling isolated in their efforts to engage students, schools and classrooms in sustainability.

In the face of a growing list of standards, high-stakes standardised tests, crowded classrooms and constant budget crises, the teachers I worked with were, however, enthusiastic and passionate about sustainability. In the following pages, I suggest ways to support teachers in their efforts to integrate sustainability into their classrooms and confront some of the barriers to educating for sustainability.

\section{Education aims and pedagogy}

The approach to sustainability education implemented during the summer programme was based on insights from three distinct fields of research and practice: education pedagogy, behaviour change and sustainability competencies (Frisk \& Larson, 2011; Redman, 2013). In creating a cohesive, interdisciplinary framework, I used four domains of knowledge (declarative, procedural, effectiveness and social) as the organising construct for various schools of thought on behaviour change; adapted sustainability competencies developed for higher education in order to make them applicable to the K-12 sector (systems thinking, foresighted thinking, stakeholder and group collaboration and change agency) and used an array of pedagogical approaches including real-world, experiential and problem-based learning. In targeting long-term behaviour change during the education programme, we focused on sustainable food and waste behaviours due to students' relative control over these behaviours (as compared to transportation, for example, given that none of the students were of legal driving age) (Redman, 2013). The goal of the programme was to build skills and knowledge for sustainability while reinforcing sustainable practices and positioning sustainable actions as the norm. The first week of the programme focused primarily on food-related sustainability issues and the second week focused on waste, although the classroom practices (for instance, composting and eating sustainable lunches) were continuous.

One of the underlying tenants guiding my approach is the need to move beyond declarative knowledge when targeting behaviour change. Many education programmes proceed on the faulty assumption that information regarding socio-ecological systems will ultimately foster environmentally responsible behaviours (i.e., the informationdeficit model) (Simmons \& Volk, 2002). Behavioural scholars have, however, clearly established that the linear, information-deficit approach to education is insufficient in promoting behaviour change (Finger, 1994; Kollmuss \& Agyeman, 2002). Meanwhile, a number of sustainability education scholars have embraced diverse forms of knowledge that integrate normative components of sustainability and suggest shifting away from scientific facts as the primary discourse in sustainability (Kaiser \& Fuhrer, 2003; Frisk \& Larson, 2011; DuPuis \& Ball, 2013).

Expanding our definition of knowledge to include diverse, dynamic and subjective ways of knowing can move education beyond the typical deficit approach (Frisk \& Larson, 2011; DuPuis \& Ball, 2013; Redman, 2013). Previous research described four distinct knowledge domains in terms of prominent behavioural theories (Frisk \& Larson, 
2011; Redman, 2013) which here are briefly definedas each relates to education. Declarative knowledge is technical information or scientific facts that are often taught in lecture format, although there are a number of programmes that use hands-on activities to teach facts about the water cycle (Cutts et al., 2008). Procedural knowledge refers to process, action-related knowledge and how-to skills. Procedural knowledge can be taught through formal lesson plans (for instance, my students sorted trash they had collected into three piles: compostable, recyclable or landfill during an hour-long activity). Implementing associated classroom practices is also critical to reinforcing procedural knowledge and was a central part of the education programme (for instance, providing recycling, composting and trash bins in the classroom with prompts over the bins). Effectiveness (or impact) knowledge addresses the perceived consequences associated with different behaviours as well as beliefs about who is responsible for given outcomes. One of the central ways for enhancing effectiveness knowledge is by focusing on problems that are locally relevant and at a scale with which students feel empowered to act, while also examining the positive impact of individual and collective change. Social knowledge (i.e. norms) encompasses subjective and local knowledge including the motives, intentions and actions of other people. In order to enhance social knowledge, it is critical that sustainable behaviours are positioned as normal and the desired way to act (Frisk \& Larson, 2011; Redman, 2013).

During the education programme the knowledge domains were directly linked to diverse pedagogical approaches, including real-world, experiential and problem-based learning. For instance, the students built composting bins and created prompts with how-to information regarding the sorting and maintenance of organics for their households. Through this activity they gained procedural knowledge about building and maintaining a composting system through hands-on methods, meanwhile the inclassroom composting bin had given then two weeks of sorting experience. Throughout the programme, we rewarded and incentivised the students' participation in composting, recycling and reuse behaviours, among other things in an effort to enhance social knowledge regarding sustainable actions. Table 1 reflects more information on the links between the activities and the knowledge domains, and Redman (2013) provides more details on the education programme.

The methods used during the summer programme included formal lesson plans, classroom practices, incentives for sustainable behaviours and at-home activities (Table 1). The teachers were provided with all of the lesson plans prior to the programme as well as the essential materials for modelling sustainable behaviours (for instance, they were given reusable bamboo utensils to use during lunch rather than using disposable plastic utensils). The teachers were actively involved in the implementation of the lessons and provided insights and feedback throughout the programme. While participating in the education programme, the teachers were also enrolled in a course with other teachers that were participating in different STEM programmes. Throughout the summer, the teachers shared their experiences in the sustainability programme with their peers and provided further feedback to myself and the other researchers regarding broader insights discussed during their course (which was part of their master's degrees). The mechanism of peer-sharing was particularly useful in identifying the differing of opinions regarding sustainability amongst a larger sample of K-12 teachers. 
Table 1. Sample of activities as they relate to knowledge domains and competencies

\begin{tabular}{|c|c|c|}
\hline $\begin{array}{c}\text { Activity } \\
\text { (pedagogical approach) }\end{array}$ & $\begin{array}{c}\text { Corresponding } \\
\text { knowledge domain }(\mathrm{s})\end{array}$ & Corresponding competencies \\
\hline $\begin{array}{l}\text { Students interviewed their } \\
\text { household members about } \\
\text { food purchasing decisions } \\
\text { (real-world learning) }\end{array}$ & $\begin{array}{l}\text { Social: students gained know- } \\
\text { ledge regarding the food } \\
\text { norms (both descriptive and } \\
\text { injunctive) in their households }\end{array}$ & $\begin{array}{l}\text { Stakeholder engagement: } \\
\text { Engaging students' house- } \\
\text { hold members in food } \\
\text { sustainability issues is central } \\
\text { to achieving and maintaining } \\
\text { targeted change }\end{array}$ \\
\hline $\begin{array}{l}\text { Students collected their trash } \\
\text { for a week and then sorted all } \\
\text { the trash into compostable, } \\
\text { recyclable and landfilled piles }\end{array}$ & $\begin{array}{l}\text { idents developed } \\
\text { egarding sorting }\end{array}$ & $\begin{array}{l}\text { thinking: Students } \\
\text { ed their daily activities } \\
\text { broader waste system } \\
\text { amulation of trash }\end{array}$ \\
\hline $\begin{array}{l}\text { The teachers placed stickers } \\
\text { next to students' names on } \\
\text { a poster titled "Caught } \\
\text { behaving sustainably" when } \\
\text { they noticed the students } \\
\text { participating in a sustainable } \\
\text { activity (i.e., composting or } \\
\text { using their reusable water } \\
\text { bottles) }\end{array}$ & $\begin{array}{l}\text { Procedural and social: students } \\
\text { process skills are reinforced } \\
\text { when they participate in a } \\
\text { given sustainable behavior } \\
\text { repeatedly and the sustainable } \\
\text { behaviors are positively rein- } \\
\text { forced as the norm for the } \\
\text { classroom }\end{array}$ & $\begin{array}{l}\text { Change-agency: For students } \\
\text { to lead the way for sustainable } \\
\text { change amongst their friends } \\
\text { and family, they must first be } \\
\text { equipped with the skills, con- } \\
\text { fidence, and positive attitudes } \\
\text { regarding sustainable beha- } \\
\text { viors }\end{array}$ \\
\hline $\begin{array}{l}\text { Students created action plans } \\
\text { for implementing composting } \\
\text { or recycling systems in their } \\
\text { households with the assistance } \\
\text { of their guardians }\end{array}$ & $\begin{array}{l}\text { Effectiveness: students wrote } \\
\text { action plans based on activities } \\
\text { they felt empowered to imple- } \\
\text { ment and they were positioned } \\
\text { as leaders of sustainable } \\
\text { change in their households }\end{array}$ & $\begin{array}{l}\text { Change-agency and stakehol- } \\
\text { der engagement: Rather than } \\
\text { just sending the students home } \\
\text { with composting bins (for } \\
\text { example), students co-gene- } \\
\text { rated action plans to trans- } \\
\text { form their household waste } \\
\text { system with their guardians. }\end{array}$ \\
\hline $\begin{array}{l}\text { Students calculated their } \\
\text { ecological footprints based on } \\
\text { their current behaviors and } \\
\text { then re-calculated it multiple } \\
\text { times with variations based } \\
\text { on adopting more sustainable } \\
\text { food and waste behaviors }\end{array}$ & $\begin{array}{l}\text { Declarative and effectiveness: } \\
\text { Students gained socio-ecolo- } \\
\text { gical knowledge while also } \\
\text { seeing the relative impact of } \\
\text { their behaviors on the planet }\end{array}$ & $\begin{array}{l}\text { Systems thinking: As part of } \\
\text { this activity, we connected the } \\
\text { students' daily activities to } \\
\text { broader resource use, empha- } \\
\text { sising the unintended con- } \\
\text { sequences and cascading } \\
\text { effects, often associated with } \\
\text { common consumer behaviours }\end{array}$ \\
\hline
\end{tabular}

\section{Data collection methods}

During and after the programme, I gathered data through surveys, interviews and participants' observations. Due to the small sample size, the data gathered was qualitative in nature and included photographs of the teachers' classrooms, video tapes from activities, written reflections and voice recorded responses. However, prior to participation in the summer programme, three of the teachers participated in a quantitative survey as part of a pilot test for a broader analysis on K-12 teachers' knowledge in the four domains and behaviours. Redman and Redman (2013) describe the details and full survey instrument. Although the survey instrument was in its infancy and a sample size of three makes 
quantitative analysis difficult, the survey did provide a sense of the teachers' initial knowledge in each of the domain areas as well as the sustainability-related food and waste behaviours they commonly participated in.

Table 2 describes the teachers' school positions employing pseudonyms that will be used throughout the article to protect their anonymity (in accordance with the Internal Review Board protocol). Sue was asked slightly different interview questions from the other three teachers because she did not participate in the summer programme or the pre-programme survey. Rather, she integrated a number of the activities developed for the summer programme into her classroom as part of a two-month long sustainability unit in her the $8^{\text {th }}$ form science classroom. During my visits to her classroom, I was able to take photos of the students' projects and discuss her experience with the sustainability unit. Although there are short-comings with such a small sample size, in working with only four teachers I was able to have intense and continuous collaboration and feedback during the summer programme and over the course of the year following the programme.

Table 2. Background information on the teachers involved in my research

\begin{tabular}{lll}
\hline $\begin{array}{c}\text { Teacher's } \\
\text { Pseudonym }\end{array}$ & \multicolumn{1}{c}{$\begin{array}{c}\text { Teaching position } \\
\text { (at time of interview) }\end{array}$} & \multicolumn{1}{c}{ Relationship } \\
\hline Kelly & $\begin{array}{l}1^{\text {st }} \text { year the } 8^{\text {th }} \text { form science teacher } \\
\text { at an inner-city charter school }\end{array}$ & $\begin{array}{l}\text { Participated in STEM summer } \\
\text { programme as part of master's } \\
\text { degree }\end{array}$ \\
\hline Kate & $\begin{array}{l}\text { Applying for several positions } \\
\text { as the } 8^{\text {th }} \text { form maths teacher }\end{array}$ & $\begin{array}{l}\text { Participated in STEM summer } \\
\text { programme as part of master's } \\
\text { degree }\end{array}$ \\
\hline Kylie & $3^{\text {rd }}$ year the $6^{\text {th }}$ form science teacher \\
at a suburban public school & $\begin{array}{l}\text { Participated in STEM summer } \\
\text { programme as part of master's } \\
\text { degree }\end{array}$ \\
\hline Sue & $4^{\text {th } \text { year the } 8^{\text {th }} \text { form science teacher }}$ & $\begin{array}{l}\text { Received the sustainability } \\
\text { at an inner-city public school }\end{array}$ \\
\hline
\end{tabular}

\section{Key findings}

\section{Barriers to integrating sustainability education into K-12 schools}

Herein, I discuss the key challenges of educating for sustainability as described by the teachers in this study. While there are certainly other barriers, the ones noted below are those that came up most frequently in the surveys and interviews with the teachers in this study. Some of the barriers are specific to my focus on sustainable behaviours and knowledge in diverse domains, yet others are broad barriers to any substantive change within the education system.

\section{Standards and standardised tests}

The participating teachers stressed the importance placed on standards and standardised tests at their schools. Some remarked that although they would like to teach sustainability, they feel too overwhelmed by the standards required of them and their schedules are 
just too busy to fit sustainability in their curriculum. Kelly, for instance, noted that she did not use the sustainability lessons because of "the pressure of state standards and making sure we get passing test scores”. As a first year science teacher, Kelly spoke about the pressure she felt about her students getting good AIMS (Arizona's Instrument to Measure Standards) test scores and hoped that once the tests were finished she could integrate more experiential, real-world pedagogy into her classroom. She stated, "As soon as I have more time, as soon as AIMS is over, I will be able to do more." The strong focus on content knowledge in standardised tests meant that, although Kelly understands the short-comings of declarative knowledge, she was not able to depart from information-based approaches as much as she would have liked.

Kate also discussed the difficulties of educating for sustainability while teaching traditional subjects and associated standards. In particular, Kate suggested that sustainability seems to be a better fit with science standards, but when teaching maths she would need support in learning how to create math-related sustainability lessons. Kate suggested that the most accepted sustainability issues in schools are those related to the environment, which also makes science the easiest subject for teaching sustainability. The interdisciplinary nature of sustainability is a struggle for many teachers who find that it only 'kind of' fits with their subject matterand standards.

In overcoming the barriers of standards and subjects, explicitly linking sustainability curriculum to standard subjects, expected knowledge and skills will help teachers integrate sustainability into their classrooms. There are a number of actors that can support teachers in these efforts: 1 ) universities can integrate sustainability education into their current teacher education programmes in order to explicitly link sustainability to core subjects and standards; 2) NGOs can implement sustainability workshops (i.e., continuing education courses) that focus on linking standards to sustainability; 3) outreach programmes (whether a part of universities, NGOs or businesses) can focus on developing curricula that links sustainability to core standards while also collaborating with teachers to adapt the curricula to their local context. However, it is important that even when focusing on standards, novel pedagogical approaches should be employed, rather than reverting back to lecture based methods focused solely on declarative knowledge.

\section{New teacher work-load}

The participating teachers were relatively new to their respective schools, with less than five years at their schools or in their subject areas. The first couple of years are some of the most difficult for teachers because they have to prepare lessons, presentations, worksheets and tests for a new subject that they may not even be that familiar with. In her interview, Kelly said that one of the barriers for her in implementing sustainability curriculum was her confidence regarding teaching in a new subject area.

\section{I kind of got thrown into the science area. I think a lot of meshing standards [science standards with sustainability] that you see, I don't see because I don't have that science background. I think that has a lot to do with it being harder to implement [sustainability] in the classroom because a lot of the teachers don't have confidence in the science field. (Kelly)}

For Kelly being a new science teacher is overwhelming but,as she becomes more comfortable with teaching science, she hopes to try many of the sustainability lessons 
and practices in her classroom. In this way, Kelly represents the trade-offs associated with working with new teachers. While younger teachers may be more attune and open to relatively new, emerging ideas such as sustainability, they lack the confidence and experience that seasoned teachers have. On the other hand, seasoned teachers may have the confidence and seniority to try more novel approaches but are generally less familiar with sustainability issues and practices.

As a result, I suggest the development of Professional Learning Communities (PLCs) focused on sustainability in order to encourage collaboration between seasoned and new teachers. PLC's can help foster a social norm regarding the integration of sustainability into classrooms and schools, particularly if the school establishes an incentive structure for participation in a sustainability PLC. PLCs already exist in many schools and are used to promote interdisciplinary collaboration, the development of new curriculum and co-generation and maintenance of projects (such as school gardens).

\section{Lack of deep knowledge regarding sustainability}

Lack of knowledge regarding sustainability itself can be a barrier to implementing sustainability projects and curricula. Teachers want to feel knowledgeable about the topics they are teaching and not feeling sufficiently knowledgeable can make them hesitant about teaching sustainability topics. Kelly felt that, with more training, she could gain the requisite knowledge to integrate sustainability into her classroom but right now she finds it overwhelming. Part of the problem, in Kelly's point of view, is that much of the knowledge she would like to glean cannot be attained solely through reading a book or a website, rather it requires action-related knowledge and hands-on experience. The pre-programme survey (taken by Kate, Kylie and Kelly) reinforced this point because prior to participation in the summer programme, the teachers had relatively high levels of declarative knowledge but lower levels of knowledge in the other three domains in comparison.

While Sue has a strong science background, she did note that implementing the sustainability unit was a learning process for her. Sue said, "I didn't really understand what I was getting myself into with the sustainability unit." She was learning and researching sustainability issues along with her students. While teachers traditionally like to be the 'experts' on a topic before teaching it, Sue demonstrated that as long as the teacher is willing to learn along the way, lack of deep knowledge does not have to be a barrier to implementing a sustainability unit.

From the interviews, it is clear that some teachers are more hesitant about diving into new topics and approaches while others are confident enough to learn through the process. Hence, in overcoming the knowledge barrier, it is not necessary that every teacher has perfect knowledge on the myriad of complex sustainability issues prior to integrating sustainability into their classrooms but it is important to link sustainability to diverse domains of knowledge in areas that teachers are interested in (for instance, Kylie stated she would attend a workshop on integrating food systems sustainability into K-12 classrooms). It would, therefore, be beneficial to structure workshops around the teachers' specific interests in order to delve deeper into a topic rather than focusing on surface or declarative understanding of sustainability broadly. 


\section{Lack of external and internal support}

The teachers suggested that professional development and training regarding educating for sustainability in the K-12 system is lacking and much needed. In terms of training, Kelly said, "I have always wanted to learn a more formal approach to introduce this topic [sustainability] in order to make students more aware.” Through in-service training and professional development focused on sustainability, teachers could get the support they need to develop and implement sustainability curriculum and practices.

While external collaboration and support would be beneficial, teachers also need to feel supported in their efforts to educate for sustainability by school leaders. The teachers I interviewed were concerned about teaching topics that administrators and parents would find unacceptable. For instance, Kate said, "Talking about plant-based diets as opposed to eating meat is not as socially acceptable and probably would not be well accepted by administrators and parents." Kelly also had concerns about pushing the boundaries of what is taught in part because sustainability is not traditionally a part of her school's science curriculum. If administrators were openly supportive of sustainability education then much of the concern expressed by Kelly and Kate would be alleviated.

Universities can be a part of enhancing both internal and external support. Administrators and teachers filter through the university system in order to get undergraduate (and often graduate) degrees. By integrating sustainability and diverse domains of knowledge into university courses, regardless of discipline, the graduates of universities will, ideally, be supportive of these constructs in their future careers.

\section{Opportunities for integrating sustainability education into K-12 schools}

The barriers to implementing sustainability education seem daunting; however, there are also opportunities that can be capitalised on. In particular, the teachers expressed interest in educating for sustainability and transformative change. They value a sustainable future and see K-12 education as a critical part of transitioning towards sustainability. The students are equally enthusiastic and when given the opportunity will engage deeply in sustainability issues. Additionally, sustainability curricula, when adapted by a knowledgeable teacher that has internal and external support, can meet the standards and increase students' engagement in the targeted topics.

\section{Enthusiastic teachers}

Despite teachers' heavy workload, each of the teachers I surveyed and interviewed expressed excitement about integrating one or more lessons/practices into their classrooms (Table 3). In the post-summer programme survey, Kelly wrote, "I think all the material and ideas you presented were inspiring, meaningful and important" and "I look forward to multiplying the effect in my classroom." Kate said that seeing the students' reactions to the sustainability material during the two-week programme, reminded her of how important it is for students to learn about sustainability and understand how everything is connected. Sue was also enthusiastic about sustainability education and felt that the sustainability unit was moving and powerful. She said, "I don't care what subject I am teaching I really want to teach this [sustainability] every year." The enthusiasm expressed 
by the teachers demonstrates that if they were to have support in implementing sustainability curriculum and practices they would be happy to do so.

Table 3. Sustainability lessons and practices selected by the teachers as their 'favourite'

\begin{tabular}{lll}
\hline Teacher & Favourite activity & $\begin{array}{c}\text { Justification (how and why the activity fits in } \\
\text { with the teacher's classroom) }\end{array}$ \\
\hline Kelly & $\begin{array}{l}\text { Composting and eating } \\
\text { healthy as part of } \\
\text { everyday classroom } \\
\text { practices }\end{array}$ & $\begin{array}{l}\text { Kelly is overwhelmed by the standards so she } \\
\text { prefers to integrate sustainability into her } \\
\text { classroom practices (i.e., recycling) rather than } \\
\text { in formal lessons or curriculum. }\end{array}$ \\
\hline Kate & Sorting trash activity & $\begin{array}{l}\text { Kate stated that through watching the students } \\
\text { sort their trash into compostable, recyclables } \\
\text { and landfilled piles, she was able to physically } \\
\text { see what they had learned about waste manage- } \\
\text { ment. In this way, the lesson served both as a } \\
\text { hands-on, real-world relevant activity and as an } \\
\text { assessment of what the students learned. }\end{array}$ \\
\hline Kylie & Ecological footprint & $\begin{array}{l}\text { Kyle wrote that she used the ecological foot- } \\
\text { print activity with her students on the Earth Day, } \\
\text { because "it really helped them see the impact } \\
\text { of consumer choices" and "raise consciousness } \\
\text { among students regarding the choices they make." }\end{array}$ \\
& $\begin{array}{l}\text { Sue used the cereal box re-design lesson as her first } \\
\text { activity in the sustainability unit, because it allowed } \\
\text { her students to engage in the inquiry process (which } \\
\text { is Strand } 1 \text { of the } 8^{\text {th }} \text { form science standards). }\end{array}$ \\
\hline Sue & Cereal re-design &
\end{tabular}

As previously discussed, the teachers I interviewed were relatively new teachers so it is possible that more seasoned teachers will see sustainability as just another "wave of reform" (Hargreaves \& Goodson, 2006, p. 18) and may, therefore, lack the excitement expressed by these new teachers. Other scholars have found that mature teachers with longer careers, often see reform and change as another phase that will ultimately not last so rather than engaging in the suggested change, they just try to ride it out (Hargreaves \& Goodson, 2006). Thus, in order to capitalise on the enthusiasm of the new teachers while also utilising the experience of seasoned teachers, I would reiterate the need for PLCs as a method of bringing new and mature teachers together.

\section{Student interest and engagement in sustainability topics}

Teachers are constantly seeking ways to increase student interest in learning and educating for sustainability certainly seems to get students excited and engaged in learning. Even teachers that may be less enthusiastic about sustainability as a topic may be convinced to implement some sustainability lessons in order to increase student engagement. In Sue's words:

about $99 \%$ of her students said the sustainability unit was the most important thing they learned all year...Even kids that I have never been able to touch 
all year long, I've had a whole entire year with them, kids that I have never been able to break through to, they are stopping after class asking questions, coming in at lunch, wanting to know more information.

Sue was surprised at all the outside of class time her students were spending on sustainability because typically homework is seen as a burden but with the sustainability unit the students were, "just off on their own doing their own investigating". The students commented on how because of the sustainability unit, they saw sustainability issues all around them and felt that the topic was relevant to their lives and the real-world. The problems presented in class were relevant and tangible (real-world based) and spurred conversations with the students' peers and families.

\section{Adaptability of sustainability lessons}

Sue used many of the activities and materials that I created but adapted them to fit her class schedule and structure. The first lesson she used during her sustainability unit was the cereal redesign lesson (this lesson was used about $1 / 3$ of the way through the summer programme) in which students redesign cereal boxes based on the ingredients in the product (contact author for lesson plan). The students commented that "the box lies!" and from there began to question what else was in their food that they didn't know about. By the end of this activity, the students were asking broader food system questions regarding nutrition, chemicals and food marketing.

Building upon the students' curiosity, Sue presented information on the food system beginning with the Green Revolution and industrial agriculture. She tied the Green Revolution into previous science units by having the students use this case to discuss the relationship between ethics and science. By starting with a fun, creative, hands-on activity, Sue was able to get the students asking questions and investigating on their own.

Sue also modified some of the details of certain activities. For instance, during the summer programme the students evaluated three different types (organic, conventional and local) of salsa, actual brands; not hypothetical ones, based on environmental, economic and social equity criteria. For this activity, I wrote narratives about the companies' practices and policies regarding employees, farming practices and distribution (contact the author for full lesson plan). Sue, on the other hand, had the students bring in the salsa they most frequently ate at home (homemade salsas included). The students had a few days to research the salsas and return to class with their findings regarding the life cycle of their salsas, including labour and farming practices, production and shipping operations as well as end of life management (waste processes). In Sue's adaptation, she not only used real-world salsa brands, as it is done in my original lesson, but she went beyond and used brands (or homemade equivalents) that were present in the students' everyday lives and situated the students as the researchers.

\section{Sustainability curriculum and science standards}

During the interview, Sue went through her Arizona standards book (Cambridge-based curriculum) and pointed out how the sustainability unit fit into each of the standards, strands and concepts. For instance, Sue explained that, with Strand 2: History and Nature of Science, they discussed the history of science as a human endeavour while 
integrating food issues regarding the pros and cons of biotechnology, pesticides and the mechanisation of the food industry. Sue also discussed how well the sustainability unit fit with the scientific process and inquiry (Strand 1: Inquiry Process) - "applying scientific processes, observing questions, comparing, classifying, all of this has to do with sustainability issues; it all fits well with the sustainability unit".

She explained that the sustainability unit allowed her to expand on other standards such as the changing environment, analysing environmental risks, analysing environmental benefits of human interactions with biological or geological systems, science and technology in the environment and science in personal and social perspectives. For instance, life science standards include populations of organisms and ecosystems and analysing the relationship among organisms and their environment, so the students looked at monoculture farming and how it has wiped out ecosystems. Then, by comparing food chains and food webs, they looked at the bio-accumulation of pesticides in the environment due to industrial agriculture.

Sue, having an undergraduate degree in biology, felt that any teacher with a strong science background could easily integrate sustainability into their science class. Overall she felt that the sustainability unit:

totally tied in every concept that we covered this year. It wrapped it up in a beautiful package and put a beautiful bow on it. They could just see how every aspect of science came together in the sustainability unit, from chemicals to pollution, chemical reactions, physical and chemical properties and Newtonian mechanics. They could see how there were connections with everything they have learned. It was amazing because it [the sustainability unit] brought everything together.

Table 4 illustrates Sue's approach to integrating sustainability with the state science standards for her classroom.

Table 4. Integrating sustainability education with the $8^{\text {th }}$ form Arizona science standards

\begin{tabular}{cl}
\hline $\begin{array}{c}\text { Strand 1: Inquiry process } \\
\text { Concept 1: Observations, } \\
\text { questions and hypotheses }\end{array}$ & $\begin{array}{l}\text { Sue had a school garden in which students } \\
\text { conducted experiments about how plants } \\
\text { grow under different conditions. For instance, } \\
\text { Concept 3: Analysis and } \\
\text { conclusions }\end{array}$ \\
$\begin{array}{ll}\text { Concept 4: Communication } \\
\text { students could grow plants using purchased } \\
\text { soil, hot-compost and vermin-compost and } \\
\text { then discuss the sustainability implications as } \\
\text { well as the plant growth. }\end{array}$ \\
$\begin{array}{ll}\text { Strand 2: History and nature of } \\
\text { science }\end{array}$ & $\begin{array}{l}\text { Sue discussed the Green Revolution with the } \\
\text { students, and they reflected on how the tech- } \\
\text { Concept 1: History of science } \\
\text { as a human endeavour }\end{array}$ \\
$\begin{array}{l}\text { noncept 2: Nature of scientific (pesticides, genetically modified orga- } \\
\text { nisms (GMOs), fertilizers) had negative cas- } \\
\text { knowledge }\end{array}$ & $\begin{array}{l}\text { cading effects. They discussed how plants } \\
\text { developed in the U.S. were spread to other } \\
\text { countries in which the culture (customs) and } \\
\text { even climate made the crops less successful } \\
\text { than was anticipated. }\end{array}$ \\
\hline
\end{tabular}


Sequel to Table 4.

Strand 3: Science in personal and social perspectives

Concept 1: Changes in environments

Concept 2: Science and technology in society
Sue assigned her students to read chapters from the book Garbology (by Edward Humes). They discussed the problem and watched a video on the Great Pacific Garbage Patch. Then they brainstormed solutions (composting, recycling, reusing) and we asked to present at least one solution on their sustainability unit exam.

In the $8^{\text {th }}$ form, this strand is primarily focused in concept 2. Sue discussed GMOs with her students and explained genetic drift (gene migration from GMO crops to non-GMO crops). They also discussed how this has led to monocultures and reduced genetic diversity.

Concept 3: Populations of

organisms in an ecosystem

Concept 4: Diversity, adap-

tion and behaviour

Strand 5: Physical science

Concept 1: Properties and

changes of properties in

matter

Concept 2: Motion and forces

Concept 3: Transfer of energy

When discussing the transfer of energy, students learn about entropy. Through entropy students examine what happens when we eat higher on the food chain (loss of energy, $10 \%$ rule). Students can clearly see that eating higher on the food chain results in greater energy loss.

Strand 6: Earth and space (no per- There are no concepts for the $8^{\text {th }}$ form science formance objectives for the $8^{\text {th }}$ form) in regards to this strand.

\section{Recommendations}

Based on research in academic literature, the interviews with the teachers as well as experience at other schools, I recommend: 1) teacher training focused on sustainability and enhancing sustainability in diverse domains of knowledge; 2) PLCs focused on supporting each other in developing sustainability lessons and linking seasoned teachers with newer teachers; 3 ) internal and external support for integrating sustainability into the school and classroom. These are not recommendations based on transforming the entire school system but rather tools for integrating sustainability into current K-12 schools based on the key barriers and opportunities described above. I have briefly introduced each of these recommendations throughout the text in regards to confronting specific barriers or capitalising upon unique opportunities. Table 5 provides a brief synopsis on how the below recommendations link to the education approach and barriers/ opportunities cited above. We cannot wait nor hope for a perfect school system or all the absolutely best answers but must muddle through, implementing and improving our approaches as we go. Herein, I revisit each of these recommendations and explain how they build support for sustainability education. 
Table 5. Linking recommendations to pedagogy \& the knowledge domains

\begin{tabular}{|c|c|c|}
\hline Recommendations & $\begin{array}{c}\text { Suggested linkages to } \\
\text { pedagogy }\end{array}$ & $\begin{array}{l}\text { Suggested linkages to } \\
\text { the knowledge domains }\end{array}$ \\
\hline $\begin{array}{l}\text { Develop pre-service and } \\
\text { in-service training focused } \\
\text { on novel sustainability cur- } \\
\text { ricula while also integra- } \\
\text { ting standards (i.e., reduce } \\
\text { standards barrier while fo- } \\
\text { cusing on local adaptabi- } \\
\text { lity of sustainability curri- } \\
\text { culum) }\end{array}$ & $\begin{array}{l}\text { Focus on experiential, } \\
\text { real-world curriculum } \\
\text { - Have teachers adapt su- } \\
\text { stainability lessons for } \\
\text { different subjects/stan- } \\
\text { dards and pilot the lessons } \\
\text { during the training }\end{array}$ & $\begin{array}{l}\text { - Focus training on diverse } \\
\text { domains of knowledge, } \\
\text { while shifting away from } \\
\text { declarative, information- } \\
\text { intensive approaches } \\
\text { Discuss existing social } \\
\text { knowledge and methods } \\
\text { to position sustainability } \\
\text { as the norm }\end{array}$ \\
\hline $\begin{array}{l}\text { Develop a sustainability } \\
\text { PLC that brings new and } \\
\text { seasoned teachers together } \\
\text { (i.e., assist with new teacher } \\
\text { work-load, while capitali- } \\
\text { zing on new teachers' en- } \\
\text { thusiasm) }\end{array}$ & $\begin{array}{l}\text { - Develop classroom as well } \\
\text { as school-wide projects } \\
\text { - Emphasise the interdiscip- } \\
\text { linary nature of sustain- } \\
\text { ability cross-subject pro- } \\
\text { jects }\end{array}$ & $\begin{array}{l}\text { - Create incentive struc- } \\
\text { tures for participation in } \\
\text { PLCs, hence fostering } \\
\text { positive social norms/ } \\
\text { knowledge regarding the } \\
\text { integration of sustain- } \\
\text { ability into the school }\end{array}$ \\
\hline $\begin{array}{l}\text { Foster internal and external } \\
\text { support for sustainability in } \\
\text { schools and classrooms (i.e., } \\
\text { integrate normative com- } \\
\text { ponents of sustainability } \\
\text { into admin training and } \\
\text { universities) }\end{array}$ & $\begin{array}{l}\text { - Discuss post-normal views } \\
\text { of science in universities } \\
\text { - Develop/use sustainable } \\
\text { infrastructure as a lear- } \\
\text { ning opportunity }\end{array}$ & $\begin{array}{l}\text { - Focus on social and cul- } \\
\text { tural forms of knowledge } \\
\text { that are often neglected in } \\
\text { positivistic views of science } \\
\text { - Link sustainable campus } \\
\text { operations to curriculum } \\
\text { in order to reinforce effec- } \\
\text { tiveness, social and pro- } \\
\text { cedural knowledge }\end{array}$ \\
\hline
\end{tabular}

\section{Provide teacher training (pre-and in-service) focused on sustainability}

Some teachers, like Kelly, do not have strong science backgrounds and need support in linking sustainability curriculum to their required standards. During Kelly's interview, she stated that she would like to have a teacher in-service training that focuses on sustainability. Through external support from universities and NGOs on how to integrate sustainability into their subjects and standards, some of the burden would be taken off already over-committed teachers. Teachers are currently required to take continuing education classes every year, so devoting one of the sessions to sustainability would not add to their already busy schedule. Teachers are not going to become experts on all aspects of sustainability, so it is essential that a supportive environment for teachers to learn along with students in sustainability units (as Sue did). Administrators and parents supportive of the benefits of these co-learning approaches will be necessary. By integrating sustainability and post-normal science into undergraduate and graduate programmes, deeper knowledge and acceptance of sustainability and subjective ways of knowing (for instance, effectiveness and social knowledge) would likely occur. 
There are currently NGOs, such as the Green Education Foundation (GEF, 2013) and the Sustainability Education Network (Wheeler \& Byrne, 2003), that are focusing on developing in-service training for teachers regarding sustainability. Additionally, universities, such as Arizona State University, have outreach programmes that are tasked with supporting and collaborating with teachers and students to integrate sustainability into schools (http://sustainableschools.asu.edu/). Yet, many of the existing programmes still have a nature-centric approach and focus on global issues rather than action and individual responsibility (Blumstein \& Saylan, 2007). While it is progress to see a growing number of organisations and institutions focusing on sustainability education in the K-12 sector in order to promote the transformative change need to progress towards sustainability, the training needs to move out from under the approaches common to environmental education.

\section{Develop PLCs focused on sustainability education}

While teacher training would be useful for many teachers, some teachers such as Sue already have a clear understanding of how sustainability relates to their subject and standards. For teachers like Sue, having a PLC that focuses on sustainability lessons, projects and practices would be helpful. Sue manages the school garden and she started composting in her classroom but if more teachers got involved with sustainability education, she could have support with some of these school-wide projects rather than managing them by herself. PLC's typically bring together a group of teachers and staff in order to collaborate, learn from each other and share responsibility for the targeted project (LaFee, 2003); so while Sue would benefit from having others to share the responsibility of the garden, teachers like Kelly would benefit from learning how Sue integrated sustainability with the science standards.

PLC's have also been known to increase buy-in of new projects or ideas (LaFee, 2003), therefore the development of a sustainability PLC may also encourage seasoned teachers to engage with sustainability and support newer teachers in their efforts to try novel pedagogical methods. Members of PLC's can also share their lessons and successful adaptations with their colleagues, hence reducing the workload of each individual teacher. Many schools already have PLCs and have set aside time during the school day for PLC meetings. Building upon these existing programmes and structures allows for the teachers to focus on integrating sustainability without adding to their already over-crowded schedules.

\section{Increase internal and external support for sustainability education}

Schools can be tricky political environments. In the interview with Kate, she talked about how careful she will have to be when integrating values and subjective knowledge into the classroom. In particular, new teachers have a difficult time pushing the boundaries of what is typically taught. Kate said that while she understands that declarative knowledge on its own is not enough to create change, the behaviours that can be advocated for and the values that can be taught are largely dependent upon the school environment. In terms of integrating subjective knowledge into the classroom, Sue had strong support from her administration. Sue openly discussed behaviour change in her 
classroom and even had questions on the students' exam about how they were going to change the way they ate. In terms of her administration's reaction to this approach, Sue said, "In my final evaluation [the principal] said this is exactly our mission statement, we want kids to be competitive in a global society and we want them to be community builders, we want them to make big changes at the local level and this [sustainability unit] totally goes along with everything that our school stands for."

Unfortunately, many schools are still generally stuck in the positivist view of science in which science is value-free and the teachers should not be advocating for certain behaviours or teaching controversial topics but rather just imparting 'facts' and other types of declarative knowledge. Sue was able to integrate subjective knowledge and discuss values, attitudes and behaviours in her classroom because her principal was incredibly supportive of her efforts to integrate sustainability. This support enabled Sue to fully engage her students in the normative aspects of sustainability and if more schools can take this approach to education and see it as an opportunity to foster community leaders and change agents then sustainability canmuch more successfully diffuse throughout our society. In order to increase internal support for sustainability, universities (for instance, through undergraduate and outreach programmes) and NGOs could also tailor programmes for administrators in order to increase awareness and acceptance of subjective forms of knowledge.

Even with a supportive administration, there needs to be supportive infrastructure for many of the sustainable behaviours suggested in this article to be modelled. For instance, having the water-bottle refilling stations at the schools allows teachers to model using and refilling their water-bottles. Also, having a school-wide recycling programme is essential to create the norm of recycling within the school. Much of schools' operations are run by outside businesses or the infrastructure is installed by outside businesses. If the external businesses could support schools in their sustainability initiatives by providing monetary incentives or materials at little cost (for instance, recycling bins), then the behaviours would be far easier for money-strapped school to engage in. For behaviours like recycling, supportive infrastructure is as critical as supportive policies, hence businesses are a central part of creating change within schools.

\section{Conclusion}

Drawing on the experiences, difficulties and aspirations of active teachers interested in sustainability, I have identified several key lessons and actions which can be taken to support teachers in their efforts to educate for sustainability. The challenge of educating for sustainability and transformative change in K-12 schools is not just in the hands of teachers and principals, but rather is a burden that must be shared by universities, researchers, NGOs and even parents. Transformational education change requires structural change (adding things like water bottle filling stations in order to position refillable water bottles as the norm), institutional and financial support (to build gardens and composting systems like Sue did), as well as increased support from administrators, parents and seasoned teachers. However, through collaboration and a commitment to change and action, we can build education processes that promote systems thinking, encourage long-term strategising and place a value on the future while empowering the next generation of leaders to be agents of change for sustainability. 
Progressing towards a more sustainable future requires changes in education structure, content and process (Williams, 2008). Many sustainability education scholars have suggested that this shift necessitates educating for the whole person - not just for increased literacy and cognitive outcomes, but rather, for the head, heart and hands as well in order to promote empathy, develop skills and integrate multiple ways of knowing (Sipos et al., 2008; Williams, 2008). The methods suggested throughout this article support this call for change through shifting away from modernist, positivistic approaches to education. However, there are external forces, such as university approaches and perspectives regarding science that influence the acceptability of post-normal perspectives and subjective forms of knowledge in K-12 classrooms. Further research could explore the relationship between positivistic views of science in universities and K-12 approaches to science using a more empirical approach with a larger sample of teachers.

In addition to exploring the impact of university environs on the K-12 system, further research could explore the relationship between teachers modelling sustainable behaviours and the diffusion of those behaviours amongst the student population. Based on the interviews conducted as part of this research, teachers rarely think about the impact modelling sustainable behaviours could have on their students. There is such an emphasis on formal lesson plans which leads to practices, operations, social norms and action-related knowledge often beingneglected in the education agenda.

There is also much room for further research on how to educate for diverse domains of knowledgethrough novel pedagogy without increasing the burden placed upon teachers. One promising approach is the flipped classroom (http://www.knewton.com/ flipped-classroom). Teachers can use pre-recorded videos that take the place of traditional lectures and focus on content knowledge (in other words, declarative knowledge). Students watch these videos outside of class-time and then class-time can be spent doing experiential, hands-on learning that focuses on other forms of knowledge. The flipped classroom would be particularly beneficial for schools that want accountability regarding whether or not the teacher has touched on all the standards as the videos are easily shareable with administrators and could be organised by standard. Additionally, nonprofits and non-government organisations could focus on producing the video lectures, hence reducing teacher workload while increasing external support for sustainability education. The flipped classroom is just one suggestion that would reduce commonly cited barriers to sustainability education and would allow teachers to spend less time focused on declarative knowledge when having face-time with their students.

Although, there may be resistance to novel methods of educating for sustainability in K-12 schools (by school boards, administrators, etc.), the K-12 teachers that participated in this research were interested in those activities which targeted diverse domains of knowledge through experiential, real-world approaches. Kate, Kelly and Kylie all said they would enjoy a teaching environment that allowed them to further integrate sustainability curriculum and practice and would be interested in professional development that fostered the necessary skills. The teacher that did implement an extensive sustainability unit found that not only were the students more engaged in the content but sustainability topics provided a great platform for integrating many of the standards targeted throughout the year. Teachers are well positioned to promote responsible citizenry and empower change agents of the future but they cannot do it without broader acceptance and support for educating for sustainability. 


\section{Acknowledgements}

The K-12 sustainability education outreach programmes were funded by the National Science Foundation, GK-12, Sustainable Schools Project and CAP-LTER's K-12 outreach programme, Ecology Explorers. Thanks to Dr. Kelli Larson for her guidance and support in conducting this research and preparing this article for publication.

\section{References:}

Arbuthnot, J. (1977). The roles of attitudinal and personality variables in the prediction of environmental behavior and knowledge. Environment and Behavior, 9(2), 217232.

Blumstein, D. T., \& Saylan, C. (2007). The failure of environmental education (and how we can fix it). PLoS Biology, 5(5), 973-977.

Cutts, B., Saltz, C., \& Elser, M. (2008). Insights into the interactions between educational messages: Looking across multiple organizations addressing water issues in Maricopa county, Arizona. Applied Environmental Education \& Communication, 7(1/2), 40-50.

DuPuis, E., \& Ball, T. (2013). How not what: Teaching sustainability as process. Sustainability: Science, Practice, \& Policy, 9(1), 64-75.

Finger, M. (1994). From knowledge to action? Exploring the relationships between environmental experiences, learning, and behavior. Journal of Social Issues, 50(3), 141-160.

Frisk, E., \& Larson, K. (2011). Educating for sustainability: Competencies \& practices for transformative action. Journal of Sustainability Education, 2, 1-9.

GEF (Green Education Foundation). (2013). The Green Education Foundation. Retrieved February 7, 2012, from http://www.greeneducationfoundation.org/

Hargreaves, A., \& Goodson, I. (2006). Educational change over time? The sustainability and nonsustainability of three decades of secondaryschool change and continuity. Educational Administration Quarterly, 42(1), 3-41.

Hungerford, H. R., \& Volk, T. L. (1990). Changing learner behavior through environmental education. Journal of Environmental Education, 21(3), 8-22.

Kaiser, F., \& Fuhrer, U. 2003. Ecological behavior's dependency on different forms of knowledge. Applied Psychology, 52(4), 598-613.

Kollmuss, A., \& Agyeman, J. (2002). Mind the gap: Why do people act environmentally and what are the barriers to pro-environmental behavior? Environmental Education Research, 8(3), 239-260.

LaFee, S. (2003). Professional learning communities. School Administrator, 60(5), 6-12.

Lukk, K., Veisson, M., \& Ots, L. (2008). Characteristics of sustainable changes for schools. Journal of Teacher Education for Sustainability, 9(1), 35-44.

Makrakis, V., \& Kostoulas-Makrakis, N. (2012). Course curricular design and development of the M. Sc. programme in the field of ICT in education for sustainable development. Journal of Teacher Education for Sustainability, 14(2), 5-40.

Marzano, R. J. (1990). Standardized tests: Do they measure general cognitive abilities? NASSP Bulletin, 74(526), 93-101.

Nolet, V. (2009). Preparing sustainability-literate teachers. Teachers College Record: The Voice of Scholarship in Educations, 111(2), 409-442. 
Orr, D. (1991). What is education for? The Learning Revolution, 27, 52-59.

Orr, D. (2004). Earth in mind: on education, environment, and the buman prospect. Island Press: Washington DC.

Owens, S. (2013). We teach how we've been taught: Expeditionary learning unshackling sustainability education in US public schools. Journal of Sustainability Education, $5,1-9$.

Pepper, C., \& Wildy, H. (2008). Leading for sustainability: Is surface understanding enough? Journal of Educational Administration, 46(5), 613-629.

Pooley, J. A., \& O’Connor, M. (2000). Environmental education and attitudes: Emotions and beliefs are what is needed. Environment and Behavior, 32(5), 711-723.

Ramsey, J. M. (1993). The effects of issue investigation and action training on eighthgrade students' environmental behavior. Journal of Environmental Education, 24(3), 31-36.

Redman, E. (2013). Advancing educational pedagogy for sustainability: Developing and implementing programs to transform behaviors. International Journal of Environmental \& Science Education, 8(1), 1-34.

Redman, E., \& Redman, A. (2013). Transforming sustainable food and waste behaviors by realigning domains of knowledge in our education system. Journal of Cleaner Production (In Press).

Simmons, B., \& Volk, T. (2002). Conversations with environmental educators: A conversation with Harold Hungerford. International Journal of Sustainability in Higher Education, 9(1), 68-86.

Sipos, Y., Battisti, B., \& Grimm, K. (2008). Achieving transformative sustainability learning: Engaging head, hands and heart. International Journal of Sustainability in Higher Education, 9(1), 68-86.

Sterling, S. (2003). Whole systems thinking as a basis for paradigm change in education: Explorations in the context of sustainability. Unpublished doctoral dissertation, University of Bath, Bath, the United Kingdom.

Stir, J. (2006). Restructuring teacher education for sustainability: Student involvement through a "strengths model". Journal of Cleaner Production, 14(9-11), 830-836.

UNESCO (United Nations Educational, Scientific and Cultural Organisation). (2005). Guidelines and recommendations for reorienting teacher education to address sustainability. December 12, 2005, from http://unesdoc.unesco.org/images/0014/ 001433/143370e.pdf

Wheeler, K. A., \& Byrne, J. M. (2003). K-12 sustainability education: Its status and where higher education should intervene. Planning for Higher Education, 31(3), 23-29.

Williams, D. (2008). Sustainability education's gift learning patterns and relationships. Journal of Education for Sustainable Development, 2(1), 41-49.

\section{Correspondence:}

Dr Erin Redman, Professor of Sustainability, Escuela Nacional de Estudios SuperioresUNAM, Boulevard UNAM \# 2011, Col. Predio El Saucillo y El Potrero, León, Guanajuato, CP 36969 México. Tel.: +52 (477) 1098848.

Email: erin.n.redman@enes.unam.mx 